$551.593 .653: 551.12$

\title{
Noctilucent Clouds and Solar Radiation as Received at the Surface of the Earth
}

\author{
by \\ H. Arakawa \\ Meteorological Research Institute, Tokyo
}

(Received December 2, 1958)

Mr. Malcolm Rigby, Editor of the Meteorological Abstracts and Bibliography published by the American Meteorological Society, asked me to prepare a simple "title" bibliography on the subject of Nacreous clouds (551. 593. 652) and Noctilucent clouds (551.593.653) [WMO, 1956]. I tried to prepare this subject bibliography, in which the items were arranged chronologically. There were 75 items on noctilucent clouds in Meteorological Libraries in Japan, so far as I could find. The following table shows the year-by-year frequency of these 75 items on noctilucent clouds. Noctilucent clouds were first noted by O. JESSE [1884, 1889] who called them "leuchtenden Nachtwolken" in 1889. This type of clouds is also named "luminous nightcloud." The highest and most brilliantly iridescent clouds are the noctilucent clouds which have been observed in polar latitudes at altitudes between 75 and $90 \mathrm{~km}$. Owing to their great height they remain brightly illuminated long after the sun has set with respect to the terrestrial observer.

It must be noted that the annual number of items on noctilucent clouds is likely to be roughly proportional to the intensity of observed noctilucent clouds. Roughly speaking, it seems there were four high lights in the noctilucent-clouds display, i.e., in the 1880's 1900's, 1930's and 1950's.

Direct measurement of solar radiation by means of the pyrheliometer instruments that measure the total heat of sunshine, show marked fluctuations from year to year in the intensity of this radiation as received at the surface of the earth. This subject was carefully studied by H. H. Kimball (1931) who prepared the accompanying Fig. 1.

The smoothed percentages are plotted, and a free-hand curve is drawn by Kimball himself. The marked three great depressions in the pyrheliometric readings for 1884, 1885 and 1886, are doubtless largely, if not wholly, due to the volcanic eruption of Krakatoa in 1883, the low values of 1902-1903 due to the eruptions of Pelée, Santa Maria and Colima in 1902, and the low values of 1912-1913 due to the explosion of Katomai in 1912. From July 1914 to the end of 1930 the plotted monthly values show little variation. There were no violent volcanic eruptions, and the pyrheliometric values were remarkably constant. 
If a veil of dust should actually intercept as much as one-fifth of the direct solar radiation as Fig. 1 indicates in those years the temperature of the atmosphere at the surface of the earth would be somewhat below the normal, which was proved by Humphreys (1920), and in those years reported frequencies on noctilucent clouds have exactly something in common with volcanic eruptions of explosive character that would throw great quantities of dust into the atmosphere, and hence the great depressions in the pyrheliometric readings.

In 1957, I made a short communication to the Royal Meteorological Society [ARAKAWA, 1957] regarding an apparent relation between the yield of rice (the staple food of the Japanese people) for North Japan and the mean air temperature for the two summer months July and August, during the 72 years 1883-1954. For these data the correlation between the annual yield of rice and the mean air temperature in July and August was found to be very high.

There seems to be little doubt, therefore, that a cold summer with excessive prolonged rains is the commonest cause of failure in the crops. It was also shown that, in particular, there were notably cool summers and bad crops in 1884, 1902, 1905, 1913, 1931, 1934, 1941, 1945 and 1953 as shown in Fig. 2.

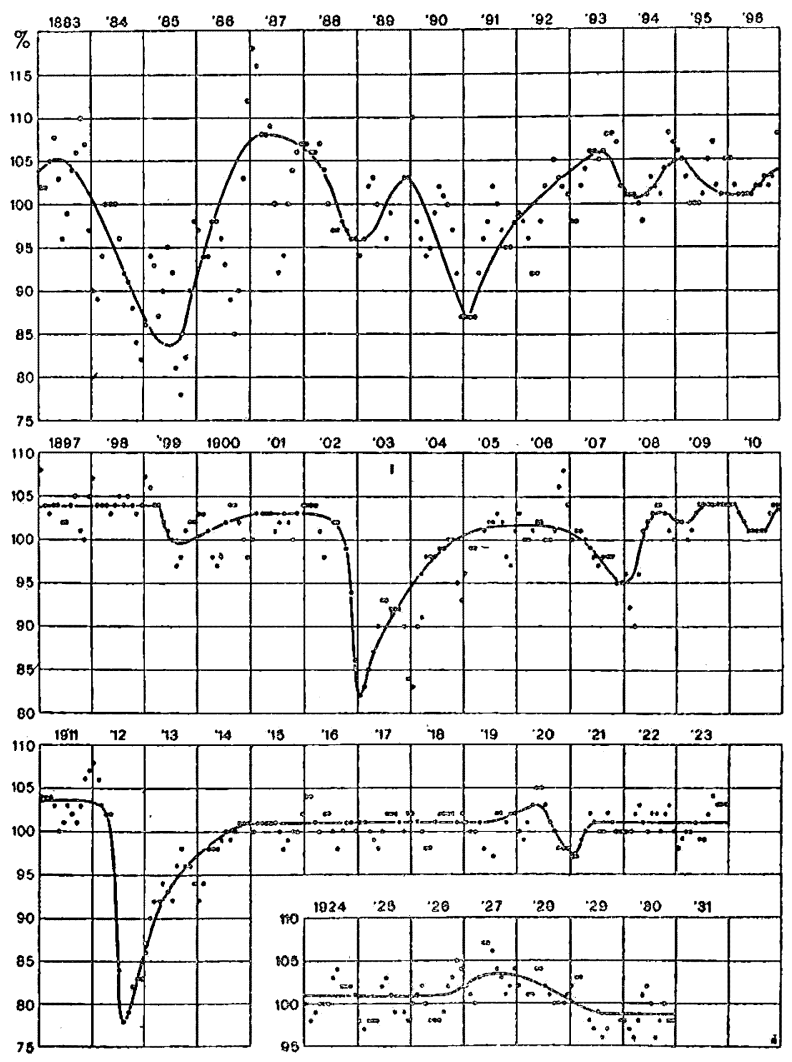

Fig. 1. Monthly average of solar radiation intensity measured at the surface of the earth, expressed by percentages of the monthly normals (after KrmbaLI). 


\begin{tabular}{|c|c|c|c|c|c|c|c|c|c|}
\hline Year & $\begin{array}{l}\text { Number } \\
\text { of items }\end{array}$ & Year & $\begin{array}{l}\text { Number } \\
\text { of items }\end{array}$ & Year & $\begin{array}{l}\text { Number } \\
\text { of items }\end{array}$ & Year & $\begin{array}{l}\text { Number } \\
\text { of items }\end{array}$ & Year & $\begin{array}{l}\text { Number } \\
\text { of items }\end{array}$ \\
\hline 1884 & \multirow{16}{*}{$\begin{array}{l}23 \\
\text { in } \\
\text { total }\end{array}$} & & \multirow{16}{*}{ 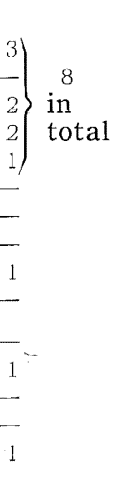 } & & & & \multirow{16}{*}{\begin{tabular}{l|l}
3 & 23 \\
6 & in \\
2 & total \\
1 &
\end{tabular}} & & \multirow{14}{*}{$\begin{array}{l}12 \\
\text { in } \\
\text { total }\end{array}$} \\
\hline 1885 & & 1900 & & 1915 & - & 1930 & & 1945 & \\
\hline 1886 & & 1901 & & 1916 & - & 1931 & & 1946 & \\
\hline 1887 & & 1902 & & 1917 & - & 1932. & & 1947 & \\
\hline 1888 & & 1903 & & 1918 & - & 1933 & & 1948 & \\
\hline 1889 & & 1904 & & 1919 & 1 & 1934 & & 1949 & \\
\hline 1890 & & 1905 & & 1920 & 1 & 1935 & & 1950 & \\
\hline 1891 & & $\begin{array}{l}1906 \\
1907\end{array}$ & & 1921 & - & 1936 & & 1951 & \\
\hline 1892 & & $\begin{array}{l}1907 \\
1908\end{array}$ & & 1922 & - & $\begin{array}{l}1907 \\
1938\end{array}$ & & 1952 & \\
\hline 1893 & & 1909 & & 1923 & - & 1939 & & 1953 & \\
\hline 1894 & & & & 1924 & 1 & & & 1954 & \\
\hline 1895 & & 1910 & & 1925 & - & 1940 & & 1955 & \\
\hline 1896 & & 1911 & & 1926 & - & 1941 & & 1956 & \\
\hline 1897 & & 1912 & & 1927 & 1. & 1942 & & 1957 & \\
\hline 1898 & & 1913 & & 1928 & 1 & 1943 & & grand & \\
\hline 1899 & & 1914 & & 1929 & - & 1944 & & total & 75 \\
\hline
\end{tabular}

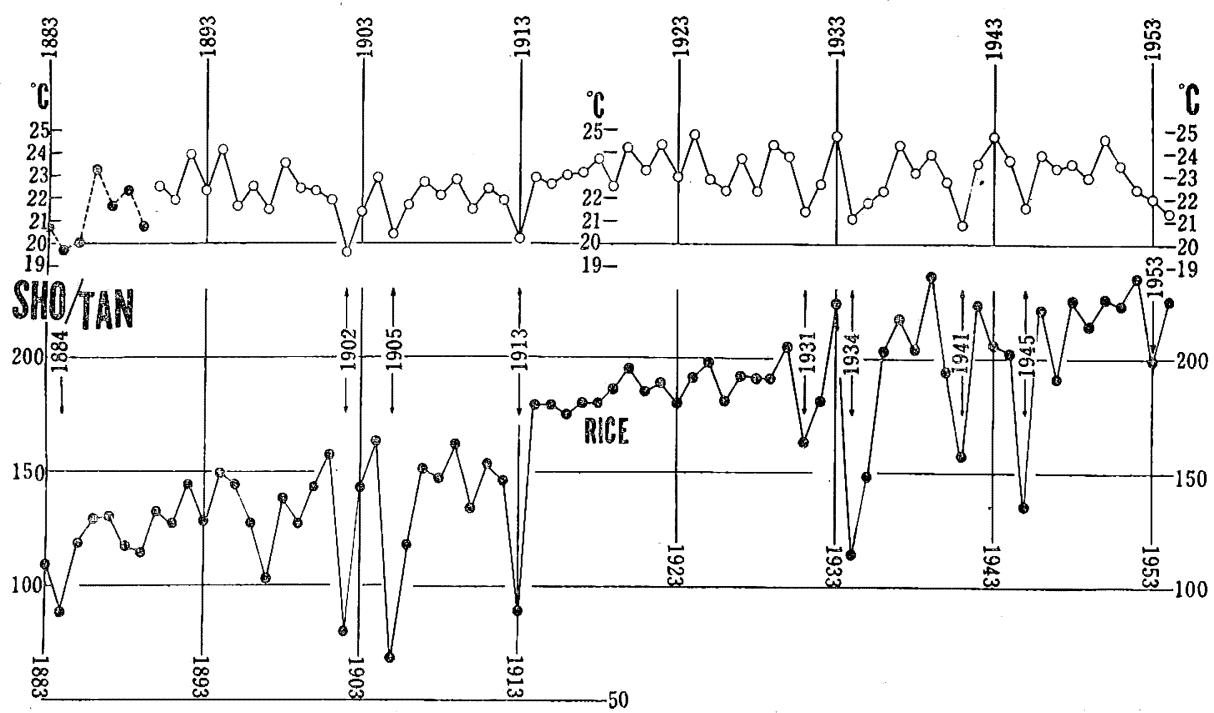

Fig. 2. Relation between the yield of rice in the Tohoku District and temperature variations, July to August, 1883-1954. The yield of rice is in Sho per Tan (1 Sho per $\operatorname{Tan}=0.2024$ bushels per acre), and the temperature in ${ }^{\circ} \mathrm{C}$. Note the yield of rice running parallel to the temperature anomalies. [ARAKAWA, 1957]

A close correspondence between the frequencies of items on noctilucent cloudsthe frequencies of observing noctilucent clouds-direct measurements of solar radiation by means of the pyrheliometer instruments-and cool summers-bad harvestswill be evident to the reader. It seems cool summers in North Japan have been caused by the stratospheric polution characterized by appearance of noctilucent clouds in the upper stratosphere; although our discussion is far from perfect. Lastly, it should be noted that the sampling of the stratospheric air for moisture as suggested by W. F. LibBy (1958) could be most efficiently done at the level of orographic nacreous clouds $(20 \sim 30 \mathrm{~km})$ with aircraft and air-filters which will collect 
the moisture, and could not be effectively done at the level of noctilucent clouds with rockets and air-filters.

\title{
References
}

ArakaWa, H., 1957: Three Great Famines in Japan, Weather, London, Vol, 12, No. 7, 211-217. Humphreys, W. J., 1920: Physics of the Air, Philadelphia, Chapters on Volcanism, 569-603; 3rd Ed., McGraw-Hill (1940).

Jesse, O., 1884: Die Höhe der Dunstschicht, durch welche die merkwürdigen Dämmerungserscheinungen der letzten Monate hervorgerufen worden sind, Meteorol. Zeitschrift, Bd. 1, 127-137; Die merkwürdigen Dämmerungserscheinungen des Herbstes und Winters 1883/84, Zeitschrift der Österreichischen Gesellschaft für Meteorologie, 19, $313-320$.

JessE, O., 1889: Die leuchtenden Nachtwolken, Meteorol. Zeitschrift, Bd. 6, 184-186.

Kimbali, Herbert H., 1931: Solar Radiation as a Meteorological Factor, Monthly Weather Review, 59, 472-479.

Libby, WiltaRd F., 1958: Isotopes in Meteorology, Bull. Amer. Met. Soc., 39, 65-68.

Sefriguchi, R., 1934: Die Leuchtenden Nachtwolken, Kagaku (Science), 3, 414. This is only report on observed noctilucent clouds in Japan.

World Meteorological Organization, 1956: International Cloud Atlas, Vol. 1, 56-57.

\section{夜 光 雲と日射の強さ}

\author{
荒川秀 俊
}

夜光雲の出現が多かつた年代（1880 年代，1900 年代，1930 年代，1950 年代）火法全世界的飞日射 の強さが減少していたこと，火山の大爆発のあとであったこと，世界の気温が全体として低く，北日本の 榉作に凶冷が起つたことなどを示し，夜光雲が蝔を主体として成立つているらしいという間接的証明を試 みた。 